\title{
けい光放電管の相互反射と輝き分布
}

\author{
専門会員 福井 和久海*

\section{Interreflection and Brightness Distribution on Fluorescent Lamps} \\ Wakumi Fukui (Fellow Member) \\ (Himeji Institute of Technology)
}

\begin{abstract}
The author tries to obtain the brightness distribution curve of a fluorescent lamp more easily by solving matrices of interreflection derived by Prof. O' Brien by means of a computer.

First of all, he divides a 20 watts fluorescent lamp into 20 parts and measures their brightness to take the ratios of them to that of the central part. And also he measures transmittances and reflectances of phosphors and a glass, radiation of ultraviolet and visible mercury rays.

Then getting shape factors between divided parts of a tube, he forms the matrices, and tries to coincide the calculated results with the measured ones changing the values of matrices, especially of the initial luminous radiances.

After many trials, he finds that inside the fluorescent lamp, ultraviolet rays interreflect with the reflectance factor about 0.7 and the consequent radiant flux density is quite high.

Next, he derives a following formula which contains the transmittance of the phosphor and the glass, and verifies it practically.

$$
L_{i} \cdot \text { out }=\tau_{g}\left[L_{o i} \cdot \text { oui } t \tau_{p} \sum_{j=1}^{m} F(i, j) L_{j} \cdot \text { in }\right\rceil
$$

\section{1. 緒 言}

けい光放電管の輝き分布については二, 三の論文 ${ }^{122}$ がすでに報告されているが，これらは相互反射を表わす 積分方程式を特定の関数で近似して解き，ついで，この 理論に基ついた测定を行なって，前者と比較するといら

た式を導いて計算を行ない，測定結果と比較することに よって，けい光放電管の輝き分布の解析に妥当な結果を 得たのでここにその概略を述べる。

あわせて、V型溝に斜めに平行な光束か入射する場合 の光束発散度, 実効反身率敊よび色ずれの計算結果も報 告卞る。
\end{abstract} 方法をとっている.

そこで筆者は同じ現象を O'Brien 教授の提唱した相 互反射の行列で表現し，これを電子計算機によってより 簡単に解くことを試みた。

この結果, 思いがけず発光機構について一つの解目を 加えることができたが，さらに汁い光膜の透過を考虑し

* 姫路工業大学

\section{2. 相互反射の理論}

\section{1 円柱内面の Shape Factor $\boldsymbol{F}(\boldsymbol{i}, \boldsymbol{j})$ と相互反射 の行列}

相互反射の行列をつくるために泣，まずShape Factor 艺計算しな计ればならないが，円柱内面では自己要素内 での相互反射があるため，これを含んだ Self Shape 
Factor を求めることになる。この計算方法3 はすでに 传土根博士らが示しておられるので，ここではその結果 そ用いて円柱を分割したときの式を導き，各分割部相互 間の Shape Factor の計算を行なった。

まず円柱の Self Shape Factor $F(i, i)$ を求める式は 次のようである.

$$
F(i, i)=1+\varepsilon-\sqrt{ } 1+\varepsilon^{2}
$$

$$
\text { ただし， } \varepsilon=\frac{H}{D}
$$

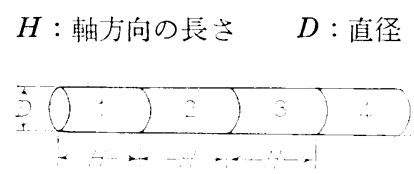

图1円柱の分割

沪えに，図1のように円柱を等分する場合にはまお゙ $F(1,1)$ が(1)式から㽡かれる.

$$
F(1,1)=1+\varepsilon-\sqrt{ } 1+\varepsilon^{2-}
$$

次に, 隣合った部分間の Shape Factor は相反法則

$$
A_{i} F(i, j)=A_{j} F(j, i) \quad A_{i} \text { : 面積 }
$$

圭用いると容易である。たと劣ば $F(1,2)$ を求わるには

$$
\left(A_{1}+A_{2}\right) F(1+2,1+2)=A_{1} F(1,1)+A_{1} F(1,2)
$$

$$
+A_{2} F(2,1)+A_{2} F(2,2)
$$

等分割のときには，

$$
\begin{gathered}
A_{1}=A_{2}, \quad F(1,2)=F(2,1), F(1,1)=F(2,2) \\
\therefore \quad F(1+2,1+2)=F(1,1)+F(1,2) \\
\therefore \quad F(1,2)=F(1+2,1+2)-F(1,1) \\
=\varepsilon+\sqrt{1+\varepsilon^{2}}-\sqrt{1+4 \varepsilon^{2}}
\end{gathered}
$$

同様にして

$$
\begin{gathered}
F(1,3)=\frac{1}{2}[3 F(1+2+3,1+2+3)-3 F(1,1) \\
-4 F(1,2)]=\varepsilon-\frac{1}{2} \sqrt{1+\varepsilon^{2}}+2 \sqrt{1+4 \varepsilon^{2}} \\
-\frac{3}{2} \sqrt{1+9 \varepsilon^{2}}
\end{gathered}
$$

一般に $i \geq 2$ のときには，次のようになる.

$$
\begin{aligned}
F(1, i)= & \varepsilon-\left(\frac{i}{2}-1\right) \sqrt{1+(i-2)^{2} \varepsilon^{2}} \\
& +(i-1) \sqrt{1+(i-1)^{2} \varepsilon^{2}}-\frac{i}{2} \sqrt{1+i^{2}} \varepsilon^{\overline{2}} \cdots(2)
\end{aligned}
$$

円柱が等分してあると, 分割部分相互の間には同じ関係 がみられるため，(2)式を計算するとすべての Shape Factor が求まる.

管端のベース部(b)と円柱分割部分との間の Shape Factor あ同様にして求められ，これを一般的な形で亦 すと次のようになる。

$$
\begin{aligned}
F(i, b)= & \frac{1}{2}\left[-(2 i-1) \varepsilon-(i-1) \sqrt{1+(i-1)^{2} \varepsilon^{2}}\right. \\
& \left.+i \sqrt{ } 1+i^{2} \varepsilon^{2}\right] \quad \ldots \ldots \ldots \ldots \ldots \ldots \ldots \ldots \ldots \ldots \ldots \ldots
\end{aligned}
$$

Shape Eactor が求まると, 反射率, 初期光束発散度
に滴当な值を入れれば，相互反射の行列をつくることが できる、今，壮い光放電管を20等分する場合を考劣る 之, 管の両端のベース部を加壳て Luminous Transfer Matrix は22行, 22列のものとなり，(4)式のよらに示さ れる。

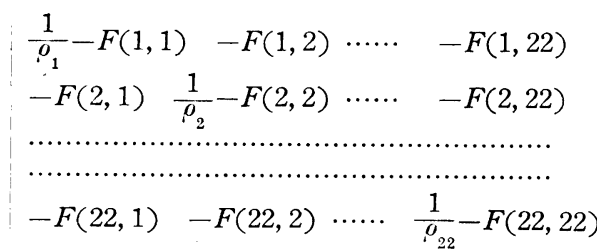

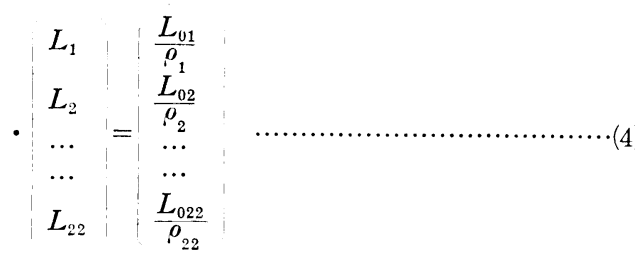

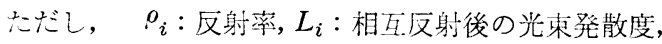
$L_{o i}:$ 初期光束発散度.

この行列は，そのまま電子計算機で解くこともできる が, 反射率は各部で等しく, 初期光束発散度も左右の各 部で詨称であるとすると，相互反射後の光束発散度も左 右対称となるから，11行11列の行列に改めることができ る.さらに，管端のベース部およびステムは管端の第 1 分割部内面の相互反射を乱しながらこれに関与している から，簡単のために，この第 1 分割部が完全に相互反射 そ行なうと仮定して，管端のベース部およびステムを無 視すると，次の10行，10列の行列が得られる。

$$
\begin{aligned}
& X(1,1) \quad X(1,2) \quad \cdots \cdots \quad X(1,10) \\
& X(2,1) \quad X(2,2) \quad \cdots \cdots \quad X(2,10) \\
& X(10,1) X(10,2) \cdots \cdots \quad X(10,10) \\
& L_{1} \quad Y_{1} \\
& \text { - } \begin{array}{l}
L_{2} \\
\ldots
\end{array}=\begin{array}{l}
Y_{2} \\
\ldots
\end{array} \\
& L_{10}: Y_{10}
\end{aligned}
$$

こうすると, 計算もその後の処理も容易になる。

相互反射の結果がさらに次の相互反射の原因になると き, 最終の光束発散度はこの過程をくり返すことによっ て求められる。(5)式を簡単のために次のように表わすと

$$
\begin{aligned}
& {\left[X_{1}\right] \cdot\left[L_{1}\right]=\left[Y_{1}\right]} \\
& {\left[L_{1}\right]=\left[X_{1}\right]^{-1}\left[Y_{1}\right]}
\end{aligned}
$$

先の相互反射の結果を用いた次の相互反射の行列は, $\left[L_{1}\right]$ あるい: $\left[L_{1}\right]$ に比例する值を Excitation Vector に入れて次のようになる。

$$
\begin{gathered}
{\left[X_{2}\right] \cdot\left[L_{2}\right]=\left[Y_{2}\right]=K\left[L_{1}\right]} \\
\therefore \quad\left[L_{2}\right]=K\left[X_{2}\right]^{-2}\left[X_{1}\right]^{-1}\left[Y_{1}\right]
\end{gathered}
$$

このように表現すると，相互反射が幾度くり返されて 
を解くことができる.

ここで反射率の值をかえようとすると, Luminous Transfer Matrix の対角楾上の各項扰よび Excitation Vector の各項の大きさを，また，初期光束発散度をか えるには Excitation Vectorの各項の大きさ在か光れば よく，管を等分割にしていると Luminous Transfer Matrix 沙刘称になる。電子融機を用いるときには, このような行列の性質を利用してプログラムを組もと, 数值を変更するときの手数をかなり省くことができる。

\section{2 けい光膜およびガラス管の透過を考慮する場合}

これまでの計算は管内面の反射だ忛を取り报って，光 束がけい光膜，ガラス管を透過すること考考てはいな いももともこの坋合は，けい光膜が薄いために内面人 の光束発散度之等しいものが外面入も出ていくと仮定し ていることであり，この仮定が近似的に成立することは

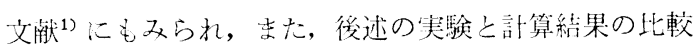
からもい光ることであるが，さらに現象を詳細に検討す るために，次のようなけい光脱およびオ゙ラス管の透過を 考虑した式觉尊いた。

$$
L_{i \text { out }}=\tau_{g}\left[L_{o i} \text { oul }+\tau_{p} \sum_{j=1}^{m} F(i, j) L_{j} \text {. in }\right]
$$

ただし， $L_{i}$. out：分割部 $i$ から外部一出る全光束発散 度, $L_{o i}$ out : 分割部 $i$ のけい光膜から外部一出る初期

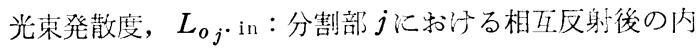
部への光束発散度, $\tau_{p}$ : けい光膜の透過率, $\tau_{g}$ : ガラス 管の透過率.

(7)式の右辺の第 2 項は，他の分割部から $i$ の部分入入 射する全光束が，この部分のけい光膜を透過することを 表わしている. な尔 $L_{\mathrm{j}}$. in は, さきの内面への相互反 射の行列を解くことによって得られている。

また，右辺の第 1 項 $L_{o i}$. out には内部への初期光束発 散度 $L_{o i} \cdot \mathrm{in}$, あるいは, 相互反射後の光束発散度 $L_{i}$. in およびこれらに比例する值を考光ることができるが，後 述するように， $L_{o i}$. in に比例する值をとるのがよいよう である.こうすると(7)式は次の形にまとめることができ る.

$$
\begin{aligned}
L_{i} \text { out } & =\tau_{g}\left[K L_{o i} \cdot \text { in }+\tau_{p} \sum_{j=1}^{m} F(i, j) L_{j} \text {. in }\right] \\
& =K L_{o i} \text {. in }+\tau_{p g} \sum_{j=1}^{m} F(i, j) L_{j} \text {. in } \cdots \cdots
\end{aligned}
$$

外部へ出る光束発散度の比をとるときには，

$$
\frac{L_{i} \text { out }}{L_{i \text { out }} \quad K L_{o i} \cdot \text { in }+\tau_{p} \sum_{j=1}^{m} F(i, j) L_{j} \cdot \text { in }+\tau_{p} \sum_{j=1}^{m} F(l, j) L_{j} \text {. in }}
$$

となり，ガラス管の透過率には無関係になる。
(7)，(8)式は，けい光がけい光膜およびがラス管を透過し て佃ていく場合であるが，けい光放電管内の水銀可視光 占よび殺菌灯からの水銀放射線のよ5に，放射が放電管 付で题こり，けい光膜，ガラス管で反射，あるい绣過 していく場合は次のよらになる。

今, 放電管の分割部 $i$ の内部で光束 $\Phi_{i}$ が発生に, 視

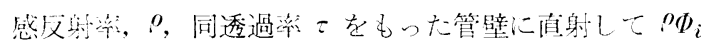

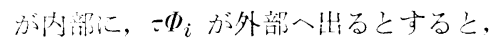

$$
\begin{aligned}
& \left.\begin{array}{rl}
L_{o i} \cdot \text { in } & =\rho \Phi_{i} \\
L_{o i} \cdot \text { out } & =\tau \Phi_{i}
\end{array}\right\} \\
& \therefore \quad \frac{L_{o i} \cdot \text { out }}{L_{o i} \cdot \text { in }}=-\frac{\tau}{\sigma}=k \\
& \therefore \quad L_{o i} \text {. out }=k L_{o i} \text {. in }
\end{aligned}
$$

分割新 $i$ から外部一出る光束発散度の式を求めると。

$$
\begin{aligned}
L_{i \cdot \text { out }} & =L_{o i \cdot \text { out }}+\tau \sum_{j=1}^{m} F(i, j) L_{j} \text { in } \\
& =k L_{o i \cdot \text { in }}+\tau \sum_{j=1}^{m} F(i, j) L_{j} \text { in }
\end{aligned}
$$

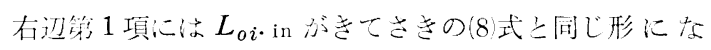
る.さらに，9式を代入すると，

$$
\begin{aligned}
L_{i \text { out }} & =\tau \Phi_{i}+\tau \sum_{i=1}^{m} F(i, j) L_{j} \text {. in } \\
& =\tau\left[\Phi_{i}+\sum_{j=1}^{m} F(i, j) L_{j} \cdot \text { in }\right] \cdots \cdots \cdots \cdots \cdots \cdots \cdots(11
\end{aligned}
$$

各部のこが等しいとみなして比をとると，次のよらにな ๖.

$$
L_{i \text {. out }}=\frac{\Phi_{i}+\sum_{j=1}^{m} F(i, j) L_{j} \text { in }}{L_{l} \text { out }} \Phi_{l}+\sum_{j=1}^{m} F(l, j) L_{j} \text { in }
$$

分光的にみるときには，各波長について娭討すればよ いから, 分光反射率を $o_{\lambda}$, 分光透過率をことすると, (10，(11)，(12) 式加

$$
\begin{aligned}
\left(L_{i} \cdot \text { out }\right)_{\lambda}= & k_{\lambda}\left(L_{o i} \cdot \text { in }\right)_{\lambda} \\
& +\tau_{\lambda} \sum_{j=1}^{m} \underset{j(i, j)}{m}\left(L_{j} \cdot \text { in }\right) ; \cdots \cdots \cdots \cdots(10)^{\prime}
\end{aligned}
$$

あるいは，

$$
\begin{aligned}
& \left(L_{i} \text { out }\right)_{\lambda}=\tau_{\lambda}\left[\Phi_{i \cdot \lambda}+\sum_{j=1}^{m} F(i, j)\left(L_{j} \cdot \text { in }\right)_{\lambda}\right] \cdots \cdots(11)^{\prime} \\
& \frac{\left(L_{i} \text { out }\right)_{\lambda}}{\left(L_{l} \text { out }\right)_{\lambda}}=\frac{\Phi_{i \cdot \lambda}+\sum_{i=1}^{m} F(i . j)\left(L_{j} \cdot \text { in }\right)_{\lambda}}{\Phi_{l} \cdot \lambda+\sum_{j=1}^{m} F(l, j)\left(L_{j} \cdot \text { in }\right)_{\lambda}} \cdots \cdots(12)^{\prime}
\end{aligned}
$$

が得られる. 放射束発散度の場合も, これを( $L_{i}$. out $]_{H}$ で示すと，ある波長範囲にわたる場合および各スペクト ルの場合で $(10),(10)^{\prime} ，(11) ，(11)^{\prime} ，(12) ，(12)^{\prime}$ と同形の式が求 められる.いずれの場合にも各分割部間の比をとると, 
けい光膜, ガラス管の透過率に関係なく内部で発生した 放射の状態上，十い光膜あるいはガラス管の反射率とで 当るるとになる。

\section{3，測 定}

\section{1 輝き分布の測定}

積分方程式を解いて輝きの分布を求める場合, これに 対応する実験を行なうとすると，微少な面積の輝きを測 定することが要求される. しかし行列を解く方法では, 全体を不連続な幾つかの部分に分割し, 各部分の平均光 束発散度を考えるため, 分割に応じた比較的大きな部分 の光束発散度を測定することになり, 実験はかなり容易 になる・

このため, 輝さの分布は放電管の任意の分割部分全体 からの放射束が受光器にはいるように,これらの間にし ゃ光板を置き，放電管を移動させて求めた，使用した放 電管は $10 \mathrm{~W}, 20 \mathrm{~W}, 40 \mathrm{~W}$ の普通形けい光放電管, $10 \mathrm{~W}$

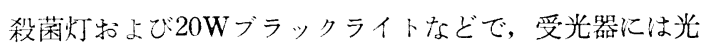
電増倍管を用いた。

紫外線に関する測定は, 殺菌灯からの放射をべックマ ン分光器で分離して行なった。な扮電源には $60 \mathrm{~Hz}$, $100 \mathrm{~V}$ および直流安定化電源を用い，管の分割は 20,40 等分小よで $20 \mathrm{~W}$ 劣い光放電管20等分のときの直径と軸 方向の長さとの比 $\varepsilon$ に等しくした分割などである.

円柱光源は，ての全長の 5 倍も離れれば点状とみなさ れるから, 以上のような分割では受光器を隔てる距離は わずかでよい，ただ，光電増倍管を用いると感度がよい のでどらしても遠ざけるようになる.しかしこれも積分 球を使用すると，入射光束が内面に一様に分布するので 距離を短縮することができる.いずれの場合でも各部分 の輝きの比をとると，その值に恙ははほとんど認められ ない.

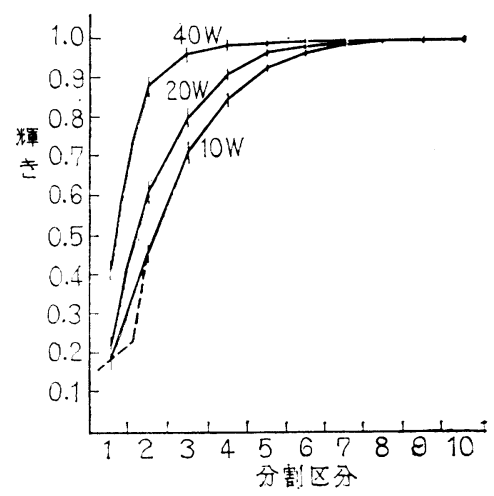

图 2 けい光放電管の数き分布

定格で点灯したときの普通形けい光放電管の輝きの分 布は図 2 のようになる。測定值には幅があり，第 2 分割
部には陰極輝点の影響がある.これは管を回転して測定 場所をかえると值が違ってくるので, 容易に確かめられ る. 図中, 破線は 2 倍の分割のときの測定值である.

\section{2 反射率, 透過率の測定}

使用した試料は, 緑, 青, 赤, 白色, 温白色の $20 \mathrm{~W}$ い光放電管と, 同種のけい光物質をガラス板に塗布焼成 したものなならび各放電管の断片およびブラックライ トの断片などであるが, けい光物質の可視域での执散反 射率の測定には, 東芝製簡易光電色沢計を, また紫外線 に対する反射率の測定には, 分光器と付属の反射率測定 装犆および UV-25 フィルタを使用した。

拡散透過率は直径 $20 \mathrm{~cm}$ の積分球に試料を取り付け, これをUVフィルタをつけた投光器で照射し, 既知のも の亡比較して求めた. このUVフィルタは投光器から放 射されている紫外線を除き，これによるけい光物質の発 光を避けるために用いた.この際, けい光物質はガラス に塗布されているので, 透過率は両者を含めたものを測 定している.

この結果, 紫外線に対するけい光物質の反射率 $\rho_{H}$ に 約 0.7 , 可視光に対するけい光物質の反射率。隹 0.6 , その透過率 $\tau$ には約 0.3 の值を得た.

より詳細な值も得られるが，計算を行なら際に $\rho_{H}, \rho$, $\tau$ 共 0.1 きざみをとり，その結果をみるとこれ以上細分 してもあまり意味のないことがわかり，また各種のけい、 光放電管の輝さの分布を測定すると個々に差があり, 測 定值にはある幅のあることがわかったので, こうした值 にとどめた。

また, これら試料の分光反射率は, 分光器と付属の反 射測定装置を使用して標準白色板と比較し, 分光透過率 はさきに述べた積分球からの光を分光器に入れ, 試料の ないとき，および既知の分光特性のものと比較して求め た。

このほか, 発光および無発光状態にあるけい光物質に 可視光を照射してその分光透過率の変化を調べた。これ には, まず積分球の入射孔前面にけい光物質を塗布焼成 したガラス板を置き, 側面から殺菌灯で励起して発光さ せるとともに, 正面からは前述のUVフィルタをつけた

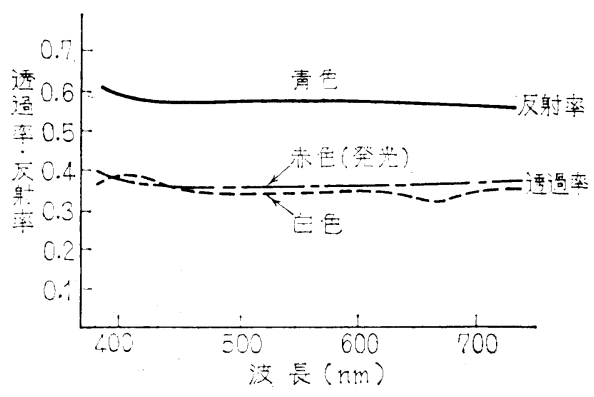

图 3 けい光物質の分光透過率および 分光反射率曲線 
投光器で照射して, 発光状態にあるけい光物質の分光透 過特性をとり，次にけい光物質の泑起をやめたときの分 光透過特性を, さらに試料を除いてその投光器の分光特 性をとり，これを比較して求めた。

測定結果のうち一例を示すと，図 3のようになる。い ずれも可視域全体にわたってほとんど平担である.

\section{4. 測定と計算過程}

20等分した $20 W け い$ 光放電管を考えることにして，ま ず，この分割に相当する Shape Factor の值を(5)式の Luminous Transfer Matrix に入れる. 次に内面への 初期光束発散度が全面にわたって等しいと仮定し, 反射 率 $\rho$ の值を変えて行列を解き, 光束発散度の分布を求め ると図 4 が得られる。

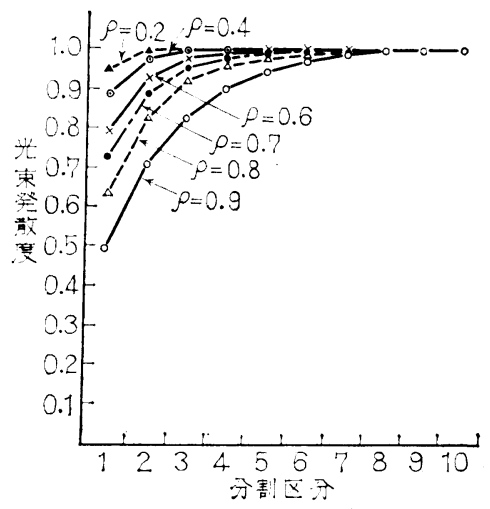

図 4 初期光束発散度が一様なときの相互反射 後の光束発散度分布 (計算値)

このうち, 反射率が 0.6 の折線と測定結果（図 2 ）之 を比較すると，両者の差があまりにも大きいのに気づ く.すなわち, 管の内面に打注初期光束発散度は決し て一様ではないということである.

このため, 次は各分割部内面の初期光束発散度を求め ることになるが，けい光物質はおもに $253.7 \mathrm{~nm}$ 線によ って励起され発光することがわかっているから，紫外線 の放射と水銀可視光の輝き分布を測定すれば，これから 推定できるはずである.

図 5 は, 20 W放電管における紫外線および水銀可視 光の輝き分布であるが，これは低王水銀放電管の放電機 構が大体一定していることに基ついて, $10 \mathrm{~W}$ 殺菌灯の測 定值から導いたものである.なお水銀可視光はけい光の 約 $1 / 10$ 程度であり, 第 2 分割部には陰極輝点の影響が出 ている。

けい光物質については, 紫外線の放射の輝きとこれに よって励起されるけい光の輝さとの比例関係が問題にな るが，殺菌灯からの紫外線をけい光物質に照射して測定 すると，両者は此例するとみなしてさしつかえないよう

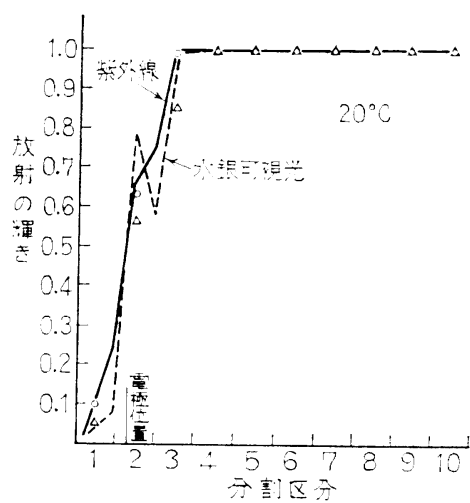

图 5 紫外線および水銀可視光の輝き分村 ……紫外線の測定值 (20分割) $\triangle \cdots \cdots$ 水銀可視光の測定值 $(20$ 分割 $)$

であった。もっとも紫外線がけい光放電管の内面で反斯 率 0.7 のもとに相互反射を行ならと。この䒠験よりかな り高い放射束発散度になっている。 それでも比例するる みなした計算結果が妥当なのをみると、このような状態 のもとでも，大体比例関係が保たれているようである.

それゆえ, 紫外線の放射の輝きに比例する值を初期光 束発散度にとって计い光の相互反射を計算なる之, 図 6 が得られる. 水銀可視光については, 直射に対する反射 分を初期光束発散度として同様に求めら扎るから, 全体 の相互反射後の光束発散度分布は, 雨者を加算して求め られるが，その結果は図6に類似していて測定値からは ずれたままである。

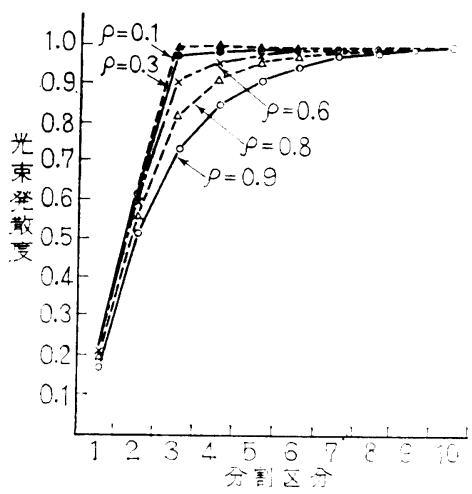

图 6 初期光束発散度を紫外線の放射の堚 きに比例させたときの相互反射传の 光束発散度分布 (計算伯)

これは, 紫外線の直射がけい光発光の主要日ではない ことを意味している.

ここで, けい光放電管の輝き分布から趉に紫外楾の放 射の輝き分布を推定すると，管端でかなり垂下するよう な分布でなければならないことに気づく。これは，紫外 線もけい光放電管の内面では比較的高い反射率のもとに 相互反射を行なっていることを暗示しているものであ り，けい光物質の紫外線に対する反射率が約 0.7 である 
ことはまさにこれを裏づけるものである。

この間の計算は $(6)$ 式に従って行なうことができるが， ここでは,さきに作った(5)式のプログラムをくり返して 使用した。まず紫外線に関する測定值を代入した行列を 解いてその相互反射後の放射束発散度を求め, 次に, こ れに比例する值を初期光束発散度とし，反射率を变えて 行列を解く.この結果が図 7である.これに水銀可視光 の相互反射分を加えて光束発散度分布を求めると図 8が 得られる.このうち, 反射率0.6の折線は図 2 の $20 \mathrm{~W}$ 心光放電管の輝き分布とかなりよく一致している.

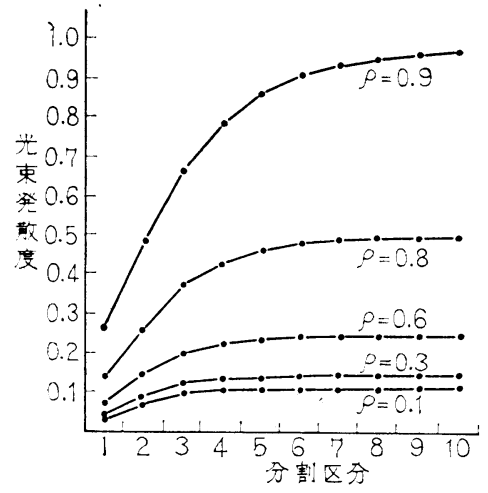

图 7 初期光束発散度を相互反射後の紫外 線の较射束発散度に比例させた之き の相互反射後の光束発散度(計算值)

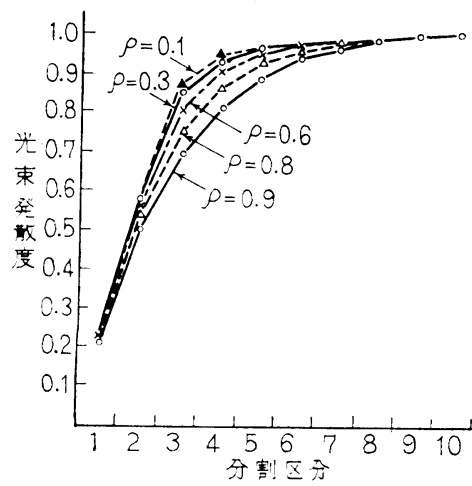

图 8 汁光放電管内面の相互反射後 の光束発散度分布（計算值）

この一致は, 以上の計算過程の妥当性を示しているこ 之になるが，また，この計算值が内面の相互反射後の光 束発散度の比であり，測定值は外面のそれであることか ら, けい光放電管の内面执よび外面の光束発散度の近似 を説明する手掛りにもなると思われる.

けい光膜などの透過を考慮した式(8)，(10)を用いると， さらに詳細な検討が可能になる. まずけい光についてみ ると, (8)式の右辺の第 1 項の外部への初期光束発散度 $L_{o i}$. out と内部への初期光束発散度 $L_{o i}$. in の比 $k$ を $1 / 3$
$1 / 2,1,2$ とし, けい光物質の紫外線に対与る反射率 ${ }_{H}$ を 0.7 , 可視部の反射率 $\rho$ および透過率 こを

$o=0.1,0.6,0.8, \quad \tau=0.8,0.3,0.1$

の間で変化したときの光束発散度分布を図示与ると, 図 9 となる.

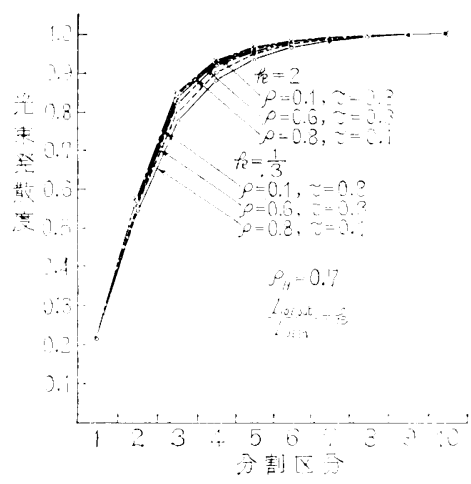

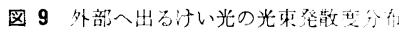
(郭算值)

ここでは，図の繁雑になるのを避けるために $k=1 / 3$, 2 の場合しか示していないが，中間の值は両者の折楾の 間にはいってくる. 大体の傾向をみると $k$ 方小さくなる 汪ど，また反射率が大きく透過率が小さくなる汪ど分布 折線は下がり，kの值が下さくなるにつれてその值に属 す分布折線の幅が広くなってくる.

$$
\begin{aligned}
& \text { また }, \quad \rho=0.6, \quad k=1 / 2, \quad \rho_{H}=0.6,0.7,0.8 \\
& \tau=0.4,0.3,0.2
\end{aligned}
$$

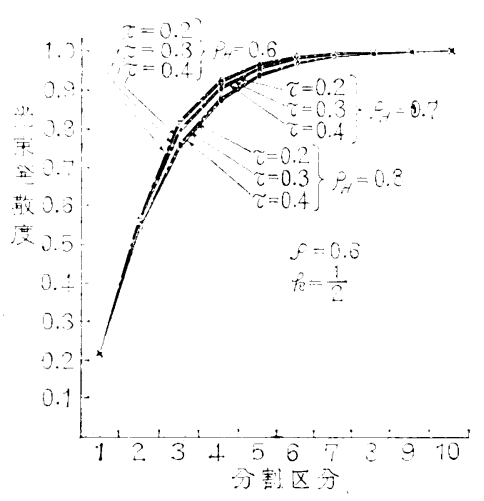

图 10 外部人出る计い光の光束登散璂心施 〈計算値〉

のように変化させたときの光束発散度分布を求めると, 図 10 が得られる。この場合には $0_{H}$ が大きくなるほど， また透過が大きいほど分布折線は下がってくる。

ちなみに， $L_{o i}$. out を内部への相互反射後の光束発散 度 $L_{i}$. in に比例させて計算を行なうと，ての值は管端 に近つくにつれて以上のものよりしだいに大きくなり， かえって測定結果からのずれが著しくなる。

水銀可視光は10式に従って前者亡同様に計算される 
が，常にkは約 $1 / 2$ である。なお輝きの測定結果および その他の条件が似ているので計算結果も類似し，このた め，両者を加算しても忛い光の場合の結果にほぼ等しい ものになる。

以上の結果を主とめると，

$$
\rho_{H}=0.7, \quad \rho=0.6, \quad \tau=0.3, \quad k=1 / 2
$$

の分布折線が測定結果とかなりよく一致高ることが見出 される。このうち， $\rho_{H}, \rho, \tau$ は測定值であり， $k$ の值 も文献2 に文ら礼る值と近似しているから。この缺算も 妥当な過程で行なわれたと思われる。

もっとも、第 $1 ， 2 ， 3$ の各分割部分には多少測定值 との差異が認るら和る。このうち,ずれが比較的大き く、かつ測定値ぶ一定しないのは第 2 分割部で，一般に 測定值が計算徝よりも大きくなる。

この原因は,フタラメントとその上に生じている陰極 輝点で, 計算の際, 数值にはこの区間の平均值をとるた め，部分的な変化を表わし得ないことおよび測定上から は輝点, フイラメント, 受光器の相対的な位㯰関係化よ って輝点の影響が変化することなどがあげられる。なお ニイル状のフィラメントは, 非対称な障害物として相互 反射に影翌し，測定方向によって少し異なった結果をも 仿らすとも考无られる。

第 1 分割部で法，まず計算上の仮定が問題になる。管 端ベース部 $b$ と他の部分との間の Shape Factor $を(3)$ 式 から求めると,

$F(1, b)=0.2231, F(2, b)=0.0367, F(3, b)=0.0098$ となり，管端くース部の影響は第 1 分割部について考慮 すればよいことがかかる。しかし，この部分にはステム があって，内面の相互反射を乱しながらこれ関与して いるためすナで述べたようにベース部およびステムを 無視し，管端の第 1 分割部が円柱の一部として妨げられ ることなく相互反射を行ならとみなした。したがって， この仮定からのずれが䛊差となって現われてくる.

专九測定の立場から反る之，水銀の放射線は管端から フィラメントに向かって低い做から急に增大していくた ら，その平均值の読文取りが困難で，これに基づいた計 算結果と測定值との間にずれを起こしやすい。しかし， そのずれの大きさは，第 2 分割部のそれに比べるとわず かである。

第 3 分割部では, フィラメントの前方にある暗部とそ の付近からの放射の輝きのこまかな変化が，その平均值 に基づく計算結果をずれさせる。しかしその大きさもき わ方て少ない。

\section{5. 色 ず れ}

図 3 に示されているように，忛い光物質はその種類の いかんにかかからず，分光反射率，分光透過率は共に可
視域全体にわたってほとんど平担である。このため，初 期光束発散度亡相互反射後の光束発散度との比が反射率 に対して変わっても, 李た Shape Factor の值の変化 が大きくても色ず机は起こり得ない。

実際に各分割部の分光特性をとって色度を計算する と，輝点の影響之思われる部分が少し青方向にずれるだ けで，他注とんど同一の色度熙をとる。

\section{6. 普通形けい光灯の輝き分布}

これまでは20 W计い光放電管について述べたがそその 他の勫通形计い光放電管が同様な汁い光物質, 同じ発光 機構㧍よび類似した電極構造をもっていることを考える と, 当然その輝き分布にも共通性が見出せるはずであ る.このため，次のような工夫のもとに共通な輝き分布 折線を作ることを試みた。

まず，各種類の放電管の分割は Shape Factor がほぼ 近似与るようにとる，次に紫外線の放射の輝きが大体直 線的に增加する部分と，平坦な部分に分けられることか らこの境界を起点にとることにし，これに相当する位置 を各管で定める，そしてこの境界から中央に向から区間 は各管とも同じ範囲に収める。したがって，管の長短に 応じて戍上の分割数は異なっている。のこ境界からフィ ラメントまでの区間は，眓上適当な長さにとって各管と も同じ間隔で値を記入する。これは低気恃水銀放電管の 電極付近の状態が類似していることによるものである. なおこの部分には，輝点の影響があることを考慮に入れ なければならない。

フィラィントから口金までの区間は，その長さが管の 大きさによって異なり，構造上にも多少の変化がある部 分なのでどうしても相互の間化少しずれが起こる。この ため,この区間㹥基準としたけい光放電管を図上汇記入 した後, 他のものは同じょらにフィラメントの側から值 を記入していく。

こらすると, 普通形けい光放電管の輝き分布は大体 1 本の折線で表示することができる，として，けい光物質 の反射率，透過䔞などが違ってくると折線の傾斜の度合 いが異なって表わされてくる。

\section{7. 殺菌灯およびブラックライト}

殺菌灯からの放射は(10)式で示され，これが測定値とな るから，䈯密にい光ば内面の相互反射に基づく分も加和 って測定されている．しかし透過率が大きいため，第 1 項の透過光が全体の傾向を決め，相互反射による分はほ とんど影響しない。放電によって発生する量を式から求 めても同じことがいえる。

ブラックライトは，使用目的どおり紫外線源として放 射の輝き分布を求めると，普通形のけい光放電管の場合 
と同じになる。なおこれを可視域で娭討しても類似した 傾向が得られるっにすききない。

之れは，二の汗い光物質から出る可視光はUV-D 1 によって涪しんじ吸收され，水銀可視光も404.7および $435.8 \mathrm{~nm}$ 維が透過するだけなので，(11)式行良って計算 することになり，透過率に関係がなくなるためである。

湘定維果を又ると, けい光收電管に比べて管ごとの差 が大きく，同一管でも左右が非対称になることがあっ t.

これは、，管に特殊なガラスＵV－D１在使用するため 㹕品に导らかできるからだと思われる。

\section{8. 普通形けい光放電管の直流点灯}

けい光放電管圭直流で焦灯する亡, 陽極側之陵極側で 輝きの分布が異なり，非対称になる。守なわり，㓌極側

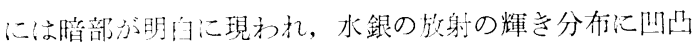
が著しくなる。このため，けい光の相互反射が起こった 後も輝き分布は交流点灯の場合よりなからかさを欠く.

これに対して陽極側では，電極直前にわずかに暗部が みられるだけなので，水鎅による放射は陽極グロ一部ま で汪添一様となり，これをすぎると急に減少するような 変化を示古. このため, けい光の相互反射が起こっても ての輝き分布はな就な減衰を示している。この過程の 計算には非刘称のため，20行，20列の行列を用いなけれ ばならない.

\section{9. 点灯時間の影響}

点灯時間老長くしても，一般にその輝き分布は変わ的 ないよらである。もっとも陵極輝点のある部分では, そ れが時間の龵過とともに移動していくため, 测定值に変 動が目だつ，てしてやがてこの部分に黒化が起こり始め ると，当然輝导は減少する。この滄か点灯時間が增すと 左右の対称性の㙕すことが悡められる。

\section{0. 温度の影 響}

低父圧の水銀蒸気の放電は温度に依估することが大き いので, 温度を变化して水銀の放射㧍よびけい光放電管 の輝き分布を測定してみた。ただし設備のつごう上，10 Włい光放電管之殺菌灯を用いている.

測定結果を示寸と，紫外線については図 11，水銀可 視光では図 12 のようになる.いずれも第3 分割部に陰 極輝点の影整がみられ, 温度が高くなると着しく輝きが 増加する. 相互反射後に相当するけい光放電管の媈き分 布は図 13 のようになり，高温になると高輝度の輝点の 影䇾を受け七管端の輝きが全体として上昇する。

また直流点灯の場合には，低温になると陽極側の輝き の減少が著しい(ダークェンド効果).

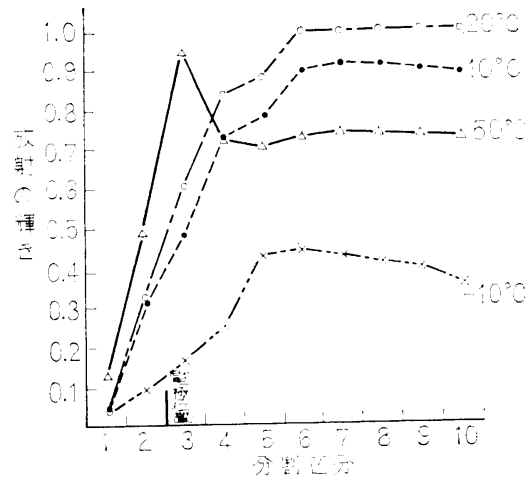

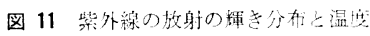
( $10 \mathrm{~W}$ 殺菌灯)

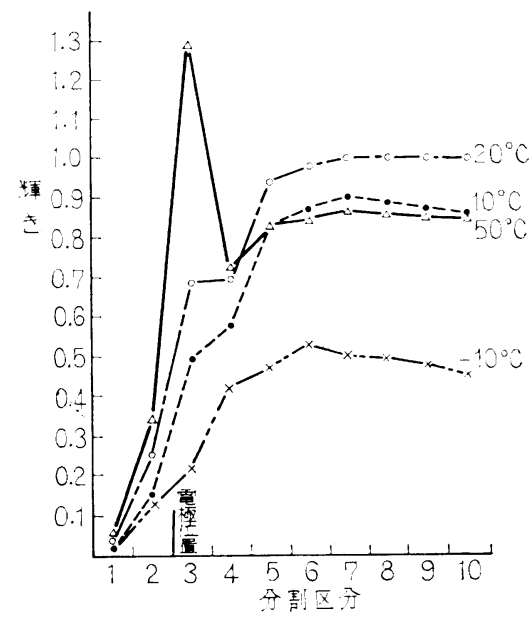

図 12 水银叮視光の䡣き分布上温度 (10 W 殺菌灯)

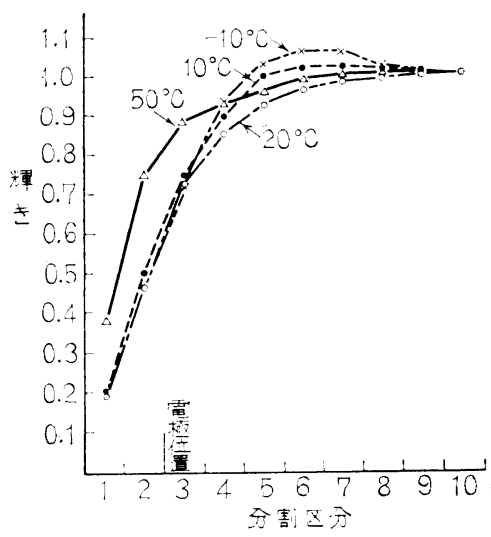

図 $1310 \mathrm{~W}$ 光放電管の輝总分布之温度

\section{1. 考察}

（1）けい光物質を管の内面に沈着させるとき，その工 程からみて，管の軸方向で膜厚にもらの起こることが考 えられる，行列を使ら場合，このようなをらはそれに対 応する分割部の反射率，透過率の変化にして解けばよい 
から個々の場台でも簡単に処理できる。また，管端に市 るフィラメント, 補助陽極, ステムなどが相互反射汇及 活寸影響も，これらの值の变化汇置き替省ることがで

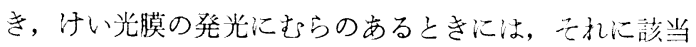
する分割部分の初期光束発散度を変克ればよい。この注 か, 輝点の影響をこれを含む部分の初期光束発散度の增 加汇置き替克るのも一案である。

(2) 管の分割は必要伈じて自由汇変えることができ る・たとえば等分割にすると，中央部付近の各分割部の 輝きの差異は少ないから，この部分の分割を大きく之 り，端へ向からにつれて細分することも考克られるし， 必要な一定部分だけを細かく分割することも可能で市 る・ただしこのような分割にすると， Shape Factor の計算がややめんどうになる。

（3）以上の計算方法は，ディジタル計算機を使用して 結論に到達する過程であるが，ソフトウェアに要する時 間を考穴る之, 照明計算器（L．A.C.）に上るほうが 現象の変化をより早くとら光得たのではないかと思われ る.

終わりに，实験に亦たって，測定誤差とか室温の変化 などで，必ずしも正しい測定結果が得られたといいにく いが，かなり妥当な所まで解析することができたと考光 る次第である。

\section{2. 結言}

この計算と垁験を行なうにあたり，電子計算機NEA C 2230 の使用には, 神戸商科大学および本学の宮脇, 広 村, 弘海原諸氏のご援助の两ったこと，また実験には寺 岡君をはじめ, 卒業研究に従事した学生諸君の努力に負 うところの多かったこと，ことに，試料の製作には東芝 姫路工場の安藤, 近藤両氏のご厚意によったことを述べ て深く感謝を表わす次第です。また Shape Factor の計 算にあたってご示唆をいただいた本学营原助教授，拉よ び松下電器照明研究所の估土根博士にはここで厚くお礼 中し上げます。

\section{参 考 文 献}

（1）黑沢：東芝レビュー 17 (昭37） 927

(2) 竹田：照学誌 44 （昭35） 131

（3）佐土根・森田・猪野原：照学誌 49 (40) 4

(4) E. M. Sparrow, V. K. Jonsson : J. Opt. Soc. Amer. 53 (1963) 816

\section{付 録}

\section{軸方向に分割した円すい孔の Shape Factor}

円すい孔斜めに平行な光束が入射する場合を検討し ょらとすると，軸を含む平面でこれを2 分割以上にしな 壮ればならないが，こうするとその Shape Factor の計 算が困難になる。

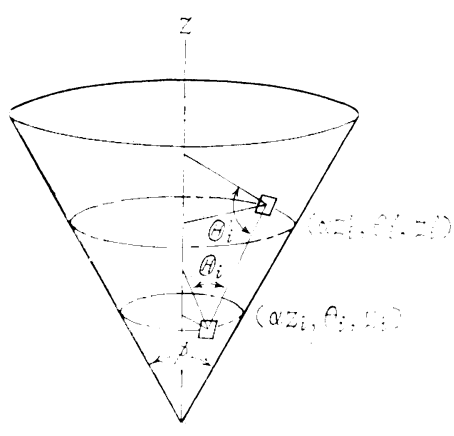

付図 1

付図 1 亿おいて, 2 点の座標を $\left(\alpha z_{i}, \theta_{i}, z_{i}\right),\left(\alpha z_{i}^{\prime}\right.$, $\left.\theta_{i}{ }^{\prime}, z_{i}{ }^{\prime}\right)$,

$$
\text { ただし }, \quad \alpha=\tan \frac{\phi}{2}
$$

$\phi:$ 円古孔頂角 $(1)^{\prime}$

とし， 2 点間の距離を $r_{i i^{\prime}}$ ，これらの点の上に之った微 少面積を $d A_{i}, d A_{i}{ }^{\prime}$, 面素 $d A_{i}, d A_{i}{ }^{\prime}$ の法線とそ机的

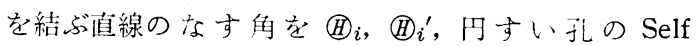
Shape Factor を $F(i, i)$ とすると,

$$
\begin{aligned}
& r_{i i^{\prime}}=\left\{\left(1 \alpha+{ }^{2}\right)\left(z_{i}{ }^{\prime}-z_{i}\right)^{2}+2 \alpha^{2} z_{i}{ }^{\prime} z_{i}\left\{1-\cos \left(\theta_{i}{ }^{\prime}-\theta_{i}\right)\right\}\right. \\
& \cos \mathbb{B}_{i}= \\
& \frac{\alpha z_{i}^{\prime}\left\{1-\cos \left(\theta_{i}^{\prime}-\theta_{i}\right)\right\}}{\left(1+\alpha^{2}\right)^{\frac{1}{2}}} \overline{2 \alpha^{2} z_{i}^{\prime}\left\{1-\cos \left(\theta_{i}^{\prime}-\theta_{i}\right)\right\}+\left(1+\alpha^{2}\right)} \frac{\left(\boldsymbol{z}_{i}^{\prime}-z_{i}\right)^{2}}{j^{\frac{1}{2}}} \\
& d A_{i}=\alpha\left(1+\alpha^{2}\right)^{\frac{1}{2}} z_{i} d z_{i} d \theta_{i} \\
& \therefore \quad F(i, i)=\frac{1}{\pi A_{i}} \int_{A_{i}} \int_{A_{i^{\prime}}} \frac{\cos \left(\mathbb{A}_{i} \cdot \cos \mathbb{B}_{i}{ }^{\prime}\right.}{r_{i i^{\prime}}{ }^{2}} d A_{i} d A_{i^{\prime}} \\
& =\frac{1}{4 \pi A_{i}} \int_{0}^{1} \int_{0}^{2} \pi \int_{0}^{1} \int_{0}^{2} \pi\left\{\frac{1-\cos \left(\theta_{i}^{\prime}-\theta_{i}\right)}{\beta-\cos \left(\theta_{i}^{\prime}-\theta_{i}\right)}\right\}^{2} \\
& d \theta_{i} d z_{i} d \theta_{i}{ }^{\prime} d z_{i}{ }^{\prime} \cdots \ldots \ldots \ldots \ldots \ldots \ldots \ldots \ldots(2)^{\prime} \\
& \text { ただし }, \quad \beta=1+\frac{1}{2}\left(1+\alpha^{2}\right) \frac{\left(z_{i}{ }^{\prime}-z_{i}\right)^{2}}{z_{i}{ }^{\prime} z_{i}}
\end{aligned}
$$

变数を変換すると,

$$
\begin{aligned}
F(i, i) & =\frac{1}{4 \pi A_{i}} \int_{0}^{1} \int_{0}^{1} \int_{0}^{2 \pi}\left\{\begin{array}{l}
1-\cos \omega \\
\beta-\cos \omega
\end{array}\right\}^{2} d \omega d z_{i} d z_{i}{ }^{\prime} \\
& =\pi \bar{A}_{i} \int_{0}^{1} \int_{0}^{1}\left\{1-\begin{array}{c}
\beta+2 \\
\beta+1
\end{array}\left(\begin{array}{c}
\beta-1 \\
\beta+1
\end{array}\right)^{\frac{1}{2}}\right\} d z_{i} d z_{i}{ }^{\prime} \cdots(4)^{\prime}
\end{aligned}
$$

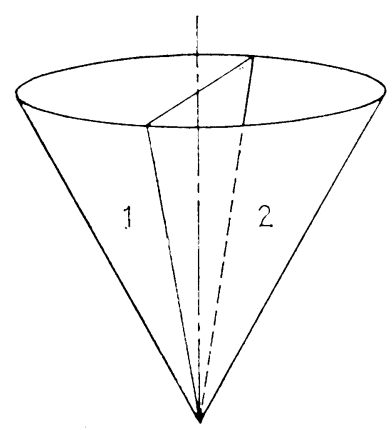

付图 2 
2 付図のような分割では, $(2)^{\prime}$ 式の積分範囲は $\int_{0}^{1} \int_{0}^{\pi} \int_{0}^{1}$ $\int_{0}^{\approx}$ となり，これを計算すると，

$$
\begin{gathered}
F(1,1)=F(2,2)=\frac{1}{2 \pi A_{1}} \int_{0}^{1} \int_{0}^{1} \int_{0}^{\pi}(\Pi-\omega) \\
\cdot\left(\frac{1-\cos \omega}{\beta-\cos \omega}\right)^{2} d \omega d z_{i} d z_{i}{ }^{\prime}
\end{gathered}
$$

となるが, $\int_{0}^{\pi} \omega\left(\frac{1-\cos \omega}{\beta-\cos \omega}\right)^{2} d \omega$ の計算ができない.しか し積分範国を $0 \rightarrow 2 \pi$ とすると, 次のように解ける。

$$
\int_{0}^{2 \pi} \omega\left(\frac{1-\cos \omega}{\beta-\cos \omega}\right)^{2} d \omega=2 \pi^{2}\left\{1-\frac{\beta+2}{\beta+1}\left(\frac{\beta-1}{\beta+1}\right)^{\frac{1}{2}}\right\}
$$

これは, 微少円すい台の表面積を面素として計算を始好 ることに等しい.

相反法則からも同様なことがいえる。

$$
\begin{aligned}
F(i, i)= & F(1+2,1+2) \\
= & F(1,1)+F(1,2) \\
= & \frac{1}{2 \pi A_{1}} \int_{0}^{1} \int_{0}^{1} \int_{0}^{\pi}(\pi-\omega)\left(\frac{1-\cos \omega}{\beta-\cos \omega}\right)^{2} d \omega d z_{i} d z_{i}{ }^{\prime} \\
& +\frac{1}{2 \pi A_{1}} \int_{0}^{1} \int_{0}^{1} \int_{0}^{\pi} \omega\left(\frac{1-\cos \omega}{\beta-\cos \omega}\right)^{2} d \omega d z_{i} d z_{i}{ }^{\prime} \\
= & \frac{1}{2 \pi A_{1}} \int_{0}^{1} \int_{0}^{1} \int_{0}^{\pi} \pi\left(\frac{1-\cos \omega}{\beta-\cos \omega}\right)^{2} d \omega d z_{i} d z_{i} \\
= & \frac{\pi}{2 A_{1}} \int_{0}^{1} \int_{0}^{1}\left\{1-\frac{\beta+2}{\beta+1}\left(\frac{\beta-1}{\beta-1}\right)^{\frac{1}{2}}\right\} d z_{i} d z_{i}{ }^{\prime}
\end{aligned}
$$

積分できない項が打ち消し合って，(4)’式と同じ結果が
得られている.この場合も分割でなく全体としてなら ば, Shape Factor が $(4)^{\prime}$ 式の形で求められることを示: している.

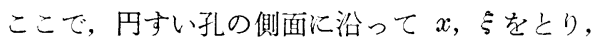

$$
z_{i}=x \cos \left(\frac{\phi}{2}\right), \quad z_{i}{ }^{\prime}=\xi \cos \left(\frac{\phi}{2}\right)
$$

としてこれを $(1)^{\prime} ，(3)^{\prime},(4)^{\prime}$ にあてはめると，

$$
\begin{aligned}
d F(x, \xi)= & \frac{\cos ^{2}\left(\frac{\phi}{2}\right)}{2 x \sin \left(\frac{\phi}{2}\right)}\{1-|\xi-x| \\
& \left.\cdot \frac{(\xi-x)^{2}+6 \xi \cdot x \cdot \sin ^{2}\left(\frac{\phi}{2}\right)}{\left.\left.\mid(\xi-x)^{2}+4 \xi \cdot x \cdot \sin ^{2}\left(\frac{\phi}{2}\right)\right]^{\frac{3}{2}}\right\}}\right\}
\end{aligned}
$$

となり，J.O.S.A. に報告された式4と同じ形のものが得 られる。

ゆえに，軸力向に分割された円すい孔の Shape Factor を求めるには，電子計算機を用いて近似值を得るか，円 すい孔を多角すい孔に近似して計算することが考えられ る.

なお，円柱を軸方向に分割する場合も同様なことがい えるよらである。

（受付1968年 3 月16日 再受付1968年 6 月 1 日) 